\title{
Spinocerebellar Ataxia Type 16
}

National Cancer Institute

\section{Source}

National Cancer Institute. Spinocerebellar Ataxia Type 16. NCI Thesaurus. Code C150250.

An autosomal recessive form of spinocerebellar ataxia caused by mutation(s) in the STUB1 gene, encoding E3 ubiquitin-protein lig ase CHIP. 